Journal of Extension Education

Vol. 28 No. 3, 2016

DOI:https: / /doi.org/10.26725/JEE.2016.3.28.5703-5708

\title{
Perceived Effectiveness of Indigenous Technical Knowledge in Dairying
}

\section{Maneesha Bhuyan ${ }^{1}$}

\begin{abstract}
A study was conducted to assess the effectiveness of indigenous technical knowledge (ITK) as perceived by 120 farm women in two villages of Haryana. The farm women rated each of six identified ITK practices based on seven parameters on a three point scale and Mean Perceived Effectiveness Index score for each ITK was then calculated. Based on this score, all six Indigenous Technical knowledge practices were categorised into three categories as less, moderate and highly effective. The practice relating to mastitis control was perceived as less effective while feeding neem leaves for endoparasite control was found to be highly effective. Extension strategies should be designed based on the perceived effectiveness of each ITK practice based on the actual users i.e., the farmers.
\end{abstract}

Keywords : Indigenous Technical Knowledge, Dairy Farming, Perceived Effectiveness, Haryana

\section{INTRODUCTION}

Enormous efforts have been made on validation of ITK practices based on judgment of researchers and in a few cases useful products have been developed. In view of cultural compatibility, social acceptability and economic viability, ITK plays a predominant role in dairy farming dominated by resource poor farm families especially women who perform more than 70 per cent of activities. Their indigenous knowledge and incidental practice of the same in the farm help to manage the dairy farming sustainably (Ponnusamy et al, 2009). Since some of the ITK practices have a significant bearing on profitability of dairy farming, the present study was undertaken to ascertain the effectiveness of prevalent ITK practices as perceived by farm women.

\section{METHODOLOGY}

The study was undertaken in 2016 under a research project of Natio-nal Dairy Research Institute (NDRI), Karnal entitled, Empowerment of farm women through livestock technologies -a collaborative project with Central Institute for Women in Agriculture

1. Research Scholar, Dairy Extension Division, ICAR-National Dairy Research Institute, Karnal, Haryana- 132001, India 
(CIWA), Bhubaneswar. Pingli in Nissing block and Jundla in Assand block of Karnal district in Haryana were indentified for project implementation. Indigenous Technical Knowledge (ITK) possessed by farm women was assessed using PRA technique. Six practices were then identified based on their expert validation from the published reports (Ponnusamy et al. 2017). Later, 60 farm women each from both the villages were requested to provide the opinion on the selected ITK practices which have been already validated by experts in order to understand the perceived effectiveness.
Perceived effectiveness implies the degree to which the farm women perceive that a positive outcome is obtainable by using a particular ITK practice in solving the field problems. It is the prception of the respondent about the attributes of the indigenous technology like relative advantage, compatibility, trail-ability, sustainability and observability. It was measured using the mean perceived effectiveness index (MPEI) methodology (Sundaramari, 2001). The index consisted of seven traits, with their relevancy weightage as given in Table 1.

Table 1.

Weightage Scores of Various Parameters of ITK Practices

\begin{tabular}{|c|l|c|}
\hline S1. No. & \multicolumn{1}{|c|}{ Parameter } & Relevancy weightage \\
\hline 1. & Cost effectiveness & 0.88 \\
\hline 2. & Adaptability & 0.76 \\
\hline 3. & Observability & 0.80 \\
\hline 4. & Trailability & 0.72 \\
\hline 5. & Complexity & 0.81 \\
\hline 6. & Relative Advantage & 0.84 \\
\hline 7. & Sustainability & 0.86 \\
\hline
\end{tabular}

The farm women were asked to rate each identified ITK practice based on these traits on a three point scale (Concurred, No idea and Not concurred). The Perceived Effectiveness Index (PEI) score of a particular ITK practice was calculated using the formula:

$$
\text { PEI score }=\frac{[W 1 R 1+W 2 R 2+\ldots \ldots \ldots+W n R n]}{[R 1+R 2+R 3+\ldots \ldots \ldots+R n]}
$$

Where,

$\mathrm{R} 1, \mathrm{R} 2, \mathrm{R} 3 \ldots \ldots . . \mathrm{R} 7$ were relevancy weights of the seven traits and

W1, W2, W3...............W7 were scores obtained for the traits for ITK from a respondent.

$$
M P E I=\frac{[P E I \text { score of a indivduval farm women for each ITK }]}{[\text { Total sample size }]}
$$

The above formula was used to calculate the Mean Perceived Effectiveness Index 
(MPEI) score for a particular ITK practice. Based on MPEI score, all the Indigenous
Technical knowledge practices were categorised into three categories:

\begin{tabular}{|c|l|l|}
\hline S1. No. & \multicolumn{1}{|c|}{ Category } & \multicolumn{1}{c|}{ MPEI Score } \\
\hline 1. & Less effective & Less than 2.00 \\
\hline 2. & Moderately Effective & $2.00-2.25$ \\
\hline 3. & Highly Effective & More than 2.25 \\
\hline
\end{tabular}

\section{FINDINGS AND DISCUSSION}

Six practices which were prevalent in both the villages were administered to 120 farm women and the responses have been calculated and presented in Table 2 .

Table 2.

Perceived Effectiveness of ITK for Addressing Various Problems in Dairy Farming

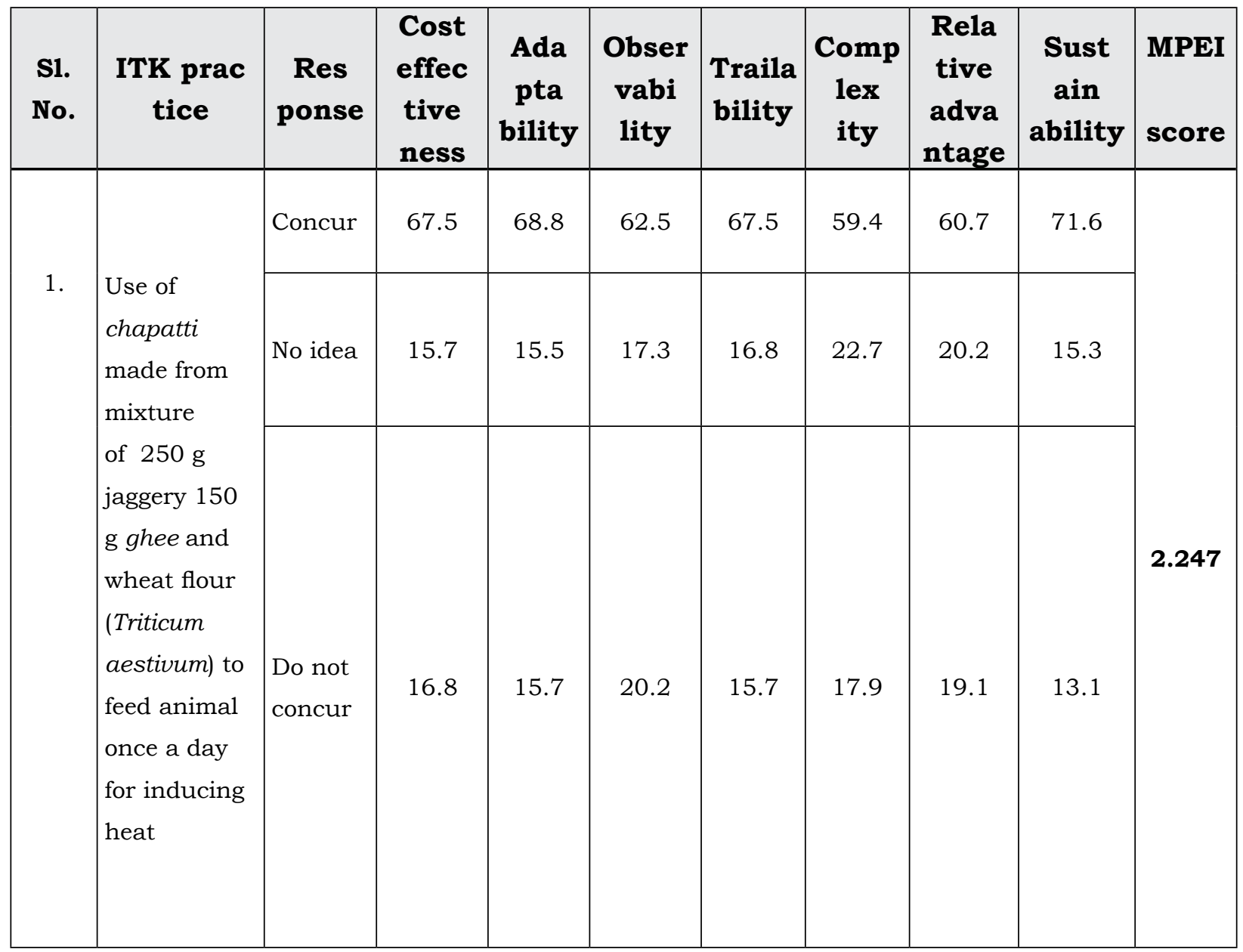


Perceived Effectiveness of Indigenous Technical Knowledge in Dairying

\begin{tabular}{|c|c|c|c|c|c|c|c|c|c|c|}
\hline $\begin{array}{l}\text { S1. } \\
\text { No. }\end{array}$ & $\begin{array}{c}\text { ITK prac } \\
\text { tice }\end{array}$ & $\begin{array}{c}\text { Res } \\
\text { ponse }\end{array}$ & $\begin{array}{l}\text { Cost } \\
\text { effec } \\
\text { tive } \\
\text { ness } \\
\end{array}$ & $\begin{array}{c}\text { Ada } \\
\text { pta } \\
\text { bility }\end{array}$ & $\begin{array}{c}\text { Obser } \\
\text { vabi } \\
\text { lity }\end{array}$ & $\begin{array}{l}\text { Traila } \\
\text { bility }\end{array}$ & $\begin{array}{c}\text { Comp } \\
\text { lex } \\
\text { ity }\end{array}$ & $\begin{array}{c}\text { Rela } \\
\text { tive } \\
\text { adva } \\
\text { ntage }\end{array}$ & $\begin{array}{c}\text { Sust } \\
\text { ain } \\
\text { ability }\end{array}$ & $\begin{array}{l}\text { MPEI } \\
\text { score }\end{array}$ \\
\hline \multirow{3}{*}{2.} & \multirow{3}{*}{$\begin{array}{l}200 \mathrm{~g} \\
\text { wheat flour } \\
\text { (Triticum } \\
\text { aestivum) } \\
\text { boiled in } \\
\text { water and } \\
\text { mixed in } \\
100 \text { gm ghee } \\
\text { and } 100 \mathrm{~g} \\
\text { jaggery apply } \\
\text { to animal } \\
\text { body for } \\
\text { retention of } \\
\text { placenta }\end{array}$} & Concur & 46.7 & 68.7 & 60.4 & 51.6 & 57.5 & 54.3 & 56.4 & \\
\hline & & No idea & 27.2 & 15.3 & 20.2 & 23.5 & 26.1 & 21.4 & 21.9 & \\
\hline & & $\begin{array}{l}\text { Do not } \\
\text { concur }\end{array}$ & 26.1 & 16 & 19.4 & 24.9 & 16.4 & 24.3 & 21.7 & 2.131 \\
\hline \multirow[t]{3}{*}{3.} & \multirow{3}{*}{\begin{tabular}{|l|} 
Application \\
of common \\
salt on \\
teats or \\
combination \\
of turmeric \\
(Curcuma \\
longa), alum \\
and black \\
pepper grind \\
and apply \\
on teats or \\
application \\
of only alum \\
or phitkari \\
on teats \\
for mastitis \\
control
\end{tabular}} & Concur & 59.4 & 37.3 & 54.3 & 35.4 & 39.6 & 40.7 & 42.5 & \multirow{3}{*}{1.998} \\
\hline & & No idea & 20.5 & 34.0 & 26.0 & 24.8 & 28.2 & 25.8 & 26.2 & \\
\hline & & $\begin{array}{l}\text { Do not } \\
\text { concur }\end{array}$ & 20.1 & 28.7 & 19.7 & 39.8 & 32.2 & 33.5 & 31.3 & \\
\hline
\end{tabular}


Journal of Extension Education

\begin{tabular}{|c|c|c|c|c|c|c|c|c|c|c|}
\hline $\begin{array}{l}\text { S1. } \\
\text { No. }\end{array}$ & $\begin{array}{c}\text { ITK prac } \\
\text { tice }\end{array}$ & $\begin{array}{c}\text { Res } \\
\text { ponse }\end{array}$ & $\begin{array}{c}\text { Cost } \\
\text { effec } \\
\text { tive } \\
\text { ness }\end{array}$ & $\begin{array}{c}\text { Ada } \\
\text { pta } \\
\text { bility }\end{array}$ & $\begin{array}{c}\text { Obser } \\
\text { vabi } \\
\text { lity }\end{array}$ & $\begin{array}{l}\text { Traila } \\
\text { bility }\end{array}$ & $\begin{array}{c}\text { Comp } \\
\text { lex } \\
\text { ity }\end{array}$ & $\begin{array}{c}\text { Rela } \\
\text { tive } \\
\text { adva } \\
\text { ntage }\end{array}$ & $\begin{array}{c}\text { Sust } \\
\text { ain } \\
\text { ability }\end{array}$ & $\begin{array}{l}\text { MPEI } \\
\text { score }\end{array}$ \\
\hline \multirow[t]{3}{*}{4.} & \multirow[b]{3}{*}{$\begin{array}{l}\text { Powder of } \\
\text { half ripe } \\
\text { bael (Aegle } \\
\text { marmelos) } \\
\text { fruit } \\
\text { +powder } \\
\text { of shisam } \\
\text { (Dalbergia } \\
\text { sissu) leaves } \\
\text { give to } \\
\text { animal for } \\
\text { diarrhoea } \\
\text { control }\end{array}$} & Concur & 52.6 & 59.7 & 70.2 & 55.1 & 61.4 & 52.5 & 61.4 & \\
\hline & & \begin{tabular}{|l|} 
No idea \\
\end{tabular} & 24.0 & 22.1 & 14.6 & 18.3 & 20.5 & 23.1 & 20.7 & \\
\hline & & $\begin{array}{l}\text { Do not } \\
\text { concur }\end{array}$ & 23.4 & 18.2 & 15.2 & 26.6 & 18.1 & 24.4 & 17.9 & 2.138 \\
\hline \multirow{3}{*}{5.} & \multirow[b]{3}{*}{$\begin{array}{l}\text { Salt added } \\
\text { to mustard } \\
\text { oil (Brassica } \\
\text { compertris) } \\
\text { applied all } \\
\text { over the body } \\
\text { for control of } \\
\text { ectoparasites }\end{array}$} & Concur & 75.6 & 56.6 & 65.4 & 65.7 & 71.0 & 47.5 & 56.7 & \\
\hline & & \begin{tabular}{|l|} 
No idea \\
\end{tabular} & 11.9 & 27.3 & 17.8 & 21.5 & 19.2 & 29.3 & 19.2 & \\
\hline & & $\begin{array}{l}\text { Do not } \\
\text { concur }\end{array}$ & 12.5 & 16.1 & 16.8 & 12.8 & 9.8 & 23.2 & 24.1 & 2.243 \\
\hline \multirow[t]{3}{*}{6.} & \multirow{3}{*}{$\begin{array}{l}\text { Feeding } \\
\text { leaves } \\
\text { of Neem } \\
\text { (Azadirachta } \\
\text { indica) to } \\
\text { animal for } \\
\text { endoparasite } \\
\text { control }\end{array}$} & Concur & 67.3 & 61.4 & 67.2 & 69.1 & 61.3 & 64.1 & 59.5 & \multirow[b]{3}{*}{2.307} \\
\hline & & \begin{tabular}{|l|} 
No idea \\
\end{tabular} & 20.5 & 25.5 & 17.6 & 19.5 & 20.9 & 16.4 & 21.9 & \\
\hline & & $\begin{array}{l}\text { Do not } \\
\text { concur }\end{array}$ & 12.2 & 13.1 & 15.2 & 11.4 & 17.8 & 19.5 & 18.6 & \\
\hline
\end{tabular}

The ITK on mastitis control was perceived to be less effective by farm women (Table 2). An NDRI study had revealed that Rs.4000 is being lost by the farmer when he misses each heat in dairy animal. ITK can play a major role in inducing heat in animals at right time. Cereals being the rich source of protein can have significant effect on inducing heat in the animals. Molasses or jaggery is added to increase palatability of mixture. (Ponnusamy et al., 2017).

Perusal of Table 2 shows that decoction prepared from wheat flour, ghee and jaggery as a treatment is practised commonly in study area instead of feeding whole plant or parts of it as a solution for retention of placenta.

Mastitis disease causes heavy economic losses and also affects the 
quality of milk. Turmeric contains curcumin, and terpenoids which work as cooling agent, astringent, antiinflammatory and antibacterial effect. This ITK practice is not perceived as so effective in curing mastitis but only aids in reducing swelling and pain in affected udders.

Diarrhoea is most common in dairy animals. The problem is more acute in calves. Bael fruit might have antidiarrhoea ingredients such as alkaloids, tannins, flavanoids, saponins and triterpenes which may be responsible for ameliorative potential of bael. Shisam (Dalbergia sissu) leaves contains alkaloids, tannins and saponins. Salt is used in certain combinations as it restores electrolytic imbalance.

Ectoparasites such as mosquitoes, flies, triatomines, fleas, bees and ticks cause severe health problems to the dairy animals. Salt added to mustard oil was perceived to be moderately effective. Use of Neem (Azadirachta indica) helps in effective control of both ectoparasite and endoparasites as it contains Azadirachtin and other compounds which act against insects such as antifeedancy, growth regulation, fecundity suppression and sterilization, oviposition repellence changes in biological fitness and blocking development of vector-borne pathogens.

\section{Implications of the study}

Documentation on mastitis control in dairy animals needs to be further explored in view of the low perceived effectiveness score. A ready to use (RTU) product prepared from well validated ITK would enhance the adoption, profitability and sustainability. There is a need to develop appropriate extension mix to disseminate the locally relevant ITK targeting the resource poor farm families. Local innovators need to be promoted as role models for outscaling the adoption of ITK.

\section{CONCLUSION}

The ITK practices used for treating various ailments of animals are wealthy traditions in animal husbandry. With the trend of modernization, knowledge of ITK practices are disappearing fast. Making use of local biodiversity is very important for treating animals at low cost. The traditional healers need to be motivated to spread this vital knowledge to future generations for promoting sustainable dairy husbandry.

\section{REFERENCES}

Ponnusamy, K., Gupta, J. \& Nagarajan, R. (2009). Indigenous Technical Knowledge (ITKs) in dairy enterprise in coastal Tamil Nadu, Indian Journal of Traditional Knowledge, 8 (2), 206-11.

Ponnusamy, K., Kale, R.B., Ravi, K.N., Arulmozhi Devi.M.C. \& Sharma, P. (2017) Cross-regional analysis on usage of Indigenous Technical Knowledge in dairy farming. Indian Journal of Animal Research, 51 (3) 2017 : 549-556.

Sundaramari, M. (2001). Adoption and perceived effectiveness of indigenous agricultural practices in different farming systems. Unpublished Ph.D thesis Gandhigram Rural Institute, Gandhigram. 